\title{
Woodrow Wilson
}

The Years of Preparation

JOHN M. MULDER

"Mulder's analysis of the impact of Wilson's religious faith upon his political and educational thought is splendid. That he brings to the task of locating Wilson within the history of Calvinist thought in America a knowledge of and sympathy for that history . . makes his analysis all the more compelling."

- The [London] Times Literary Supplement

"Mulder's intellectual biography . . . is quite simply the best account of Wilson's intellectual and moral development to appear. Although Mulder concludes with

Wilson on the threshold of his political career, in this instance what is past is

manifestly prologue. Scholarly and engaging. . . ." - Library Journal Illus. $\$ 16.50$

Write for our Religion and Philosophy Catalogue.

\section{Princeton University Press}

Princeton, New Jersey 08540

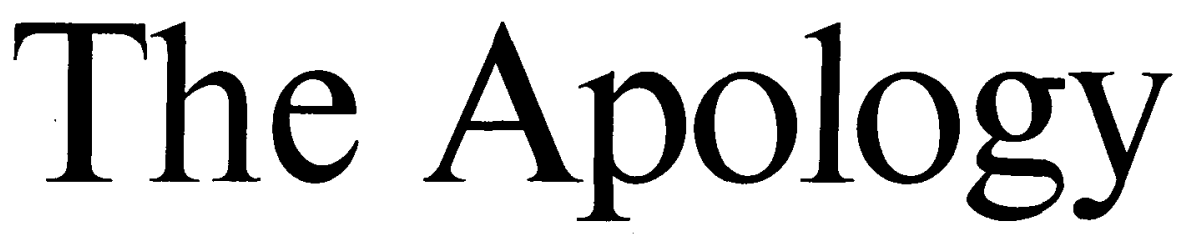

The Yale Edition of The Complete Works of St. Thomas More, Volume 9

edited by J. B. Trapp

Thomas More's Apology is one of his most significant works of religious controversy. In it he defends himself against an attack on the church made in

Christopher St. German's $A$ Treatise concerning the Division between the Spiritualty and Temporalty. This volume presents the complete text of the Apology supplemented by a thorough introduction and commentary on the issues that More addresses. Also included are a reprint of the tract by St. German and an account of the celebrated affair of Richard Hunne and

Friar Standish. Illus. $\$ 35.00$

\section{Yale University Press New Haven and London}




\section{JAROLD K. ZEMAN}

\section{THE HUSSITE MOVEMENT}

\section{AND THE REFORMATION IN}

\section{BOHEMIA, MORAVIA AND SLOVAKIA}

\section{(1350-1650)}

\section{A BIBLIOGRAPHICAL STUDY GUIDE}

(With Particular Reference to Resources in North America)

$$
\text { Michigan Slavic Publications }
$$

390 pages

ISBN 0.930042-00-X

hard cover $\$ 9.50$

Department of Slavic Languages and Literatures, The University of Michigan Modern Languages Building, Ann Arbor, Michigan 48109 